\title{
Cláudio Manuel da Costa e o caráter da história
}

\author{
Henrique Estrada Rodrigues
}

Pontificia Universidade Católica - Rio

Em 1773, Cláudio Manuel da Costa, bacharel coimbrão e poeta árcade, com atividade destacada na vida pública das Minas coloniais, conclui o manuscrito do poema épico Vila Rica, cuja primeira impressão só viria à luz em 1839. Trata-se de uma obra distribuída em dez cantos, compostos segundo preceitos normativos do século XVIII. Em língua portuguesa, por exemplo, esses preceitos conheceram uma expressão canônica sob a pena de Francisco José Freire, conhecido como Candido Lusitano, através de sua Arte Poética, ou regras da verdadeira poesia em geral, e de todas as suas espécies em particular, tratadas com juízo crítico (1748). Mas, além dessas questões de ordem poética, Cláudio Manuel também antepôs ao poema um texto em prosa conhecido como Fundamento Histórico. Era o caso de dar um chão de historicidade às ações épicas representadas em solo mineiro segundo as prescrições típicas de um gênero conhecido como 'memória histórica'. Esse gênero ganhara foros de legitimidade nas práticas acadêmicas do século XVIII, a exemplo da Academia Brasílica dos Renascidos. Fundada em Salvador em 1759, tal Academia tivera em Cláudio Manuel um de seus principais membros não residente em sua sede. A despeito de suas diferenças específicas, o poema e o Fundamento teriam este fundo em comum: representar a história da pacificação das Minas e da fundação de Vila Rica, território conflagrado, na primeira década do século XVIII, pela desordenada busca do ouro e pela guerra dos emboabas, que opusera paulistas e forasteiros recém-chegados de Portugal e da Bahia. ${ }^{1}$

De fato, esses textos recompõem, sob forma exemplar, as duas principais feições desse microcosmo colonial. A primeira diz respeito a todo um mundo em ebulição, mundo de aventureiros e potentados locais que chegaram às Minas e ocuparam os sertões antes mesmo da consolidação de qualquer rotina 
da administração colonial. Esse foi um mundo atravessado por personagens que, povoando o imaginário mineiro da primeira metade do século XVIII - como o paulista Borba-Gato ou o líder emboaba Nunes Viana -, encontraram guarida nas histórias de Cláudio Manuel. ${ }^{2}$ A segunda feição desse microcosmo, por sua vez, diz respeito à ação épica do governador Antônio de Albuquerque, enviado pelo Reino, em $170^{9}$, para pacificar os conflitos e levar aos sertões a Real Autoridade. Entre a desordem dos inícios e a chegada de Albuquerque, Cláudio Manuel desenha sua obra, preocupada em fazer, do governador, a personificação exemplar do ideal de justiça. Em outras palavras, pensados em conjunto, o poema épico e a prosa historiográfica teriam vários fios, mas um traço bem destacado: o caráter e os afetos de Antônio de Albuquerque, cuja ação exemplar determina o que deveria ser lembrado. Pensar como esse caráter se articula com o problema da história, em Vila Rica, é o objetivo deste texto. Por esse motivo, analisar como Albuquerque foi posto em obra, sob o fundo de uma intricada relação entre poesia e história, será o seu ponto de partida.

Colocar em obra um caráter: o uso dessa expressão não é aleatório. Trata-se de pensar em uma prática letrada cuja matriz é a Poética aristotélica Essa expressão aponta para um tipo muito específico de 'arte', vale dizer, para uma tékhne, entendida como "as habilidades humanas de operar e configurar, que abrange o que hoje tão fortemente distinguimos: tanto o 'artificial' como o 'artístico'. Apenas nesse sentido amplo devemos traduzir o termo 'arte". ${ }^{3}$ Já o 'caráter' tal como poeticamente representado, evoca uma dos elementos fundamentais da tragédia - por extensão, da épica -, exposto no capítulo II da Poética: "mas como os imitadores imitam homens que praticam alguma ação, e estes necessariamente são indivíduos de elevada ou de baixa índole (porque a variedade dos caracteres só se encontra nestas diferenças [e, quanto ao caráter, todos os homens se distinguem pelo vício ou pela virtude]), necessariamente também sucederá que os poetas imitam homens melhores, piores ou iguais a nós”. ${ }^{4}$

Se um caráter posto em obra torna-se 'poético' é porque poiêtike, derivado do verbo poieô, de onde poíesis, implica uma ação de fabricar, confeccionar, compor. Technê poiêtikê, ou arte poética, implica, assim, três coisas. Em primeiro lugar, uma forma especifica de racionalidade prática, ou melhor, um modo de conhecimento produtivo/técnico no qual o resultado da atividade - a obra - é tangível e de natureza diferente da do agente. ${ }^{5}$ Em segundo lugar, 
a poética traz em seu seio um conjunto de reflexões não apenas sobre 'como fazer' uma obra poética, mas também sobre 'o que é a poesia'. Por fim, como pode ser lido na obra aristotélica, a 'poética' é também um discurso crítico que, analisando obras existentes (notadamente a épica homérica e as tragédias), diz o que elas são ou deveriam ter sido. Retomada no Renascimento, quando tratativas proliferam nas mais diferentes línguas, a arte poética indica todo um corpus normativo que repensa, em novas circunstâncias, obras, conceitos e procedimentos previstos e não previstos pela matriz aristotélica. ${ }^{6}$ Fato decisivo, para esse corpus, é a releitura de Aristóteles sob a mediação da Arte Poética de Horácio, para quem

os poetas desejam ou ser úteis, ou deleitar, ou dizer coisas ao mesmo tempo agradáveis e proveitosas para a vida. (...). Arrebata todos os sufrágios quem mistura o útil e o agradável, deleitando e ao mesmo tempo instruindo o leitor ${ }^{7}$

Nos tempos e no solo de Cláudio Manuel da Costa, notadamente, a presença horaciana fora central para as tratativas sobre a poesia.

Exemplar, nesse sentido, fora a própria tradução da Arte Poética de Horácio por Cândido Lusitano (1758), onde se encontra, em versos, a passagem citada, acima, em prosa:

Ou causar instrução, ou dar deleite,

Ou unir coisas úteis a jucundas,

O poeta pretende. Se influirdes,

A brevidade amai, para que possa

Perceber-se, e reter-se o que ensinardes:

(...)

Quem sabe pois tecer ação, que instrua,

E juntamente agrade, esse é que leva

$O$ voto universal; esses poemas

Enriquecem livreiros, passam mares,

E dão ao seu autor imortal nome. ${ }^{8}$ 
E no Discurso preliminar do tradutor, Cândido Lusitano anunciava:

Há muitos séculos que os homens dedicados às boas artes veneram com especial respeito os poetas do século de Augusto; mas entre todos nenhum tem reputação mais distinta que Horácio, e talvez nenhum tem ouvido iguais louvores não menos de sábios modernos que antigos. (...) Tanto é exato e copioso em suas regras revestidas de ar poético, que ainda hoje da observância delas depende inteiramente a bondade e merecimento de qualquer Poema. ${ }^{9}$

Mas se aqui é evocado esse 'discurso', é apenas para atestar a presença, no século XVIII, de uma tradição reflexiva e normativa sobre a produção literária que só seria fortemente abalada com o advento do criticismo kantiano, do romantismo e das vanguardas artísticas, quando as noções de gênio criador ou individualidade histórica obliteram os preceitos normativos e os lugares comuns dessa tradição. Por tudo isso, vale a pena analisar a obra Vila Rica, em especial a composição poética do caráter, afeto e ações de Antônio de Albuquerque, a partir de um caminho específico: entender como o poeta mineiro aproxima e articula poesia - no caso o poema épico Vila Rica - e a memória histórica do Fundamento, e como essa articulação pretende instruir e deleitar. Mais ainda, talvez seja o caso de também pensar como a própria épica de 1773 opera um conjunto de procedimentos que articulam, poeticamente, aquilo que a teorização aristotélica pretendia separar, vale dizer, o particular da história - a narrativa do que aconteceu - e a pretendida universalidade da poesia - a representação do possível segundo a verossimilhança e a necessidade, algo mais sério e filosófico que a perspectiva do historiador. ${ }^{10}$

Tal articulação entre o particular do historiador e a universalidade poética não foi inventada por Cláudio Manuel. Mesmo no século XVIII, ilustres precedentes, a exemplo de Voltaire (em seu poema épico sobre Henrique de Navarra, a Henriade, de 1723) e Dom Francisco Xavier de Menezes (cujo poema Henriqueida, sobre Dom Henrique, personagem chave na fundação do Reino de Portugal, foi publicado em 1741) alicerçavam a poesia sobre a história, o possível e o verossimilhante sobre uma realidade documentada. ${ }^{11}$ E foi sobre tal alicerce que Voltaire e Xavier de Menezes traçaram o caráter 
e as ações de seus respectivos heróis. Cláudio Manuel opera em um registro semelhante. De fato, alguns recursos mobilizados pelos dois autores também serão usados pelo poeta mineiro. Por exemplo: notas explicativas, com remissão a documentos e/ou obras impressas que dariam chão de historicidade aos eventos narrados. Mas por que a realidade histórica, fartamente documentada, passou a ser a medida do 'possível' poético? Ou melhor - e trazendo o problema diretamente para Vila Rica -, como a história torna-se o fundamento de um caráter poético que, embora assentado sobre a vida de António de Albuquerque, ainda pretendia representar algo mais sério e filosófico que uma mera individualidade histórica?

Acompanhe-se, mais detidamente, o percurso de Cláudio Manuel. De início, cabe evocar a prosa do Fundamento Histórico. Esse texto pretende seguir a vocação historiográfica e os aparatos acadêmicos que orientavam a elaboração de uma 'memória histórica'. De acordo com Iris Kantor - em Esquecidos e Renascidos: historiografia acadêmica luso-americana, de 2004 -, pode-se dizer que esse gênero se orienta por quatro procedimentos básicos: a) elaboração de um discurso histórico que glorificasse o espaço imperial, organizando, para isso, 'memórias' e 'documentos'; b) teorização dos interesses do estado como superiores às responsabilidades religiosas, o que conduz à progressiva secularização das leis e das fontes do direito; c) definição de métodos específicos para a autenticação das fontes, com as quais se consolida a separação entre narrativa historiográfica e ficção; d) consolidação de um canal de expressão e de sociabilidade dos grupos letrados luso-americanos, com construção de uma rede de colaboradores para a coleta de informação.

A leitura do Fundamento Histórico permite reconhecer todos os traços acima descritos, uma 'memória' bem ao gosto dos aparatos defendidos pela Academia Brasílica dos Renascidos. E isso ocorre num texto rigidamente estruturado em cinco partes, que assim podem ser descritas:

$\left.1^{a}\right)$ Carta Dedicatória: seguindo a tópica tradicional da lisonja, o texto é dedicado ao Conde de Bobadela (que governou Minas entre 1752-61). O interessante é que, nessa carta, o autor também anuncia a rede conceitual que orientará seu argumento, notadamente os conceitos de 'fundação', 'pátria' e 'justiça'. Mas, se a lisonja é indício de um vassalo fiel e atento aos códigos letrados do mecenato, ou se a rede conceitual é operada como 
sutil advertência aos deveres dos governantes, uma vez que o pacto de sujeição entre o povo e o monarca não seria inviolável, tudo isso é matéria que não cabe discutir neste momento;

$\left.2^{a}\right)$ Prólogo: Dirigido ao leitor, essa parte anuncia o gênero do texto - uma memória histórica, a ser lida como fundamento do poema Vila Rica - e as razões de sua composição - celebrar as virtudes de Antônio de Albuquerque, notadamente a virtude da 'prudência', na pacificação das Minas;

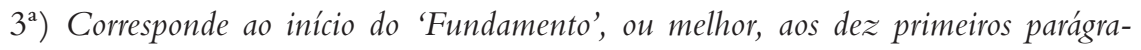
fos dessa 'memória histórica': esses parágrafos constituem um modelo de debate historiográfico. Cláudio Manuel registra as duas grandes matrizes de interpretação da guerra dos emboabas, a de Rocha Pita - que assume o ponto de vista emboaba - e a de Pedro Taques - que conta o conflito do ponto de vista dos paulistas. Em seguida, enuncia os motivos de sua adesão a Pedro Taques, entre os quais a coleta de memórias e documentos - ou seja, a busca de provas - que atestariam a veracidade dessa versão ${ }^{12}$;

$\left.4^{a}\right)$ Corresponde ao resto da narração (maior parte do texto), que vai dos momentos iniciais da descoberta do ouro à ação épica de Antônio de Albuquerque, passando por uma longa descrição sobre a guerra dos emboabas. Nessa descrição, coube até mesmo um elogio ao líder emboaba Nunes Viana - "não consta que cometesse, por si ou por algum de seus confidentes, positivamente alguma nociva ao próximo"13 -, embora esse texto elabore uma história do ponto de vista dos paulistas;

$5^{\text {a }) ~ E p i ́ l o g o: ~ o n d e ~ r e t o m a ~ u m ~ m a n u s c r i t o ~ p e r d i d o ~ d e ~ D i o g o ~ G r a s s o n ~ T i n o c o ~}$ sobre o descobrimento das esmeraldas por Fernão Dias Paes, natural de São Paulo, como se quisesse fundamentar historicamente as prerrogativas dos paulistas - e não dos emboabas - na exploração das minas pelo direito de conquista, assentado na ideia "de que os conquistadores mereciam um tratamento privilegiado da Coroa, porque eram os únicos responsáveis por um feito alcançado à custa do seu sangue, vidas e fazendas"14 15

Pois é esse texto que, batendo um chão de historicidade ao poema épico, articula crítica erudita e estratégias retórico-persuasivas, elogio aos governantes e busca de provas. O arco temporal do Fundamento é extensivo, abarcando desde a expulsão dos jesuítas das terras dos paulistas, em 1640, até uma série de eventos e de governadores coloniais, cujo último nome 
é o do Conde de Valadares, empossado em 1768. No interior desse arco, destaca-se o papel de Antônio de Albuquerque na criação de uma série de Vilas, entre as quais Vila do Carmo (hoje Mariana), Vila Rica (Ouro Preto) e Sabará. Esse papel aparece no texto numa continua progressão, sempre atestado pelo uso de 'fontes': em primeiro lugar, Cláudio Manuel descreve a passagem de antigos arraiais à condição de sedes de Câmara; em seguida, o autor demonstra como, a partir de 6 de abril de 1714, se fez a divisão das Comarcas $^{16}$, entendidas como territórios de atuação do ouvidor e corregedor. Essa divisão "consta do Livro dos Termos na Secretaria do Governo, à fl.36", atesta Cláudio Manuel. ${ }^{17}$

Mas se a 'memória histórica' se espalha numa sucessão de acontecimentos - o que Antônio de Albuquerque fez num amplo espectro temporal e espacial, bem como as repercussões futuras de seus feitos -, o poema trata de compor uma ação única - a fundação de Vila Rica - segundo um só fim - a administração da justiça segundo o modelo corporativo e hierárquico do Reino português. Candido Lusitano, em solo português, já prescrevera: a epopeia é a imitação de uma ação perfeita e de justa grandeza, de maneira a causar admiração e prazer, ao mesmo tempo em que incita a amar a virtude e as grandes empresas. Seguindo as prescrições de tratativas como a Arte Poética e Cândido Lusitano, Vila Rica é estruturado em seis partes:

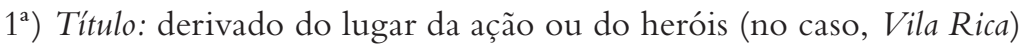

$\left.2^{a}\right)$ Proposição: onde é apresentado o assunto. Deve ser breve e sem afetação. No poema, corresponde aos 4 primeiros versos: "Cantemos, Musa, a fundação primeira / Da capital das Minas, onde inteira / Se guarda ainda, e vive inda a memória / Que enche de aplauso de Albuquerque a história”; 18

$\left.3^{a}\right)$ Invocação: quando o poeta solicita ajuda ou inspiração; veja novamente o primeiro verso: "Cantemos, Musa, a fundação primeira" (seguindo um típico lugar-comum); mas recorde-se também os versos $5^{\circ}$ ao $8^{\circ}$, quando invoca o cenário das Minas: “Tu, pátrio Ribeirão, que em outra idade / Deste assunto a meu verso, na igualdade / De um épico transporte, hoje me inspira / Mais digno influxo, porque entoe a lira";

$\left.4^{a}\right)$ Dedicação: parte optativa, que Cláudio Manuel cumpre dos versos 13 ao 20, quando dedica ao poema - como fizera no "Fundamento histórico" - ao conde de Bobadela; 
$5^{a}$ ) Narração: maior parte da epopéia, corresponde à ação principal e aos seus episódios secundários. Pode ser 'natural' (princípio, meio, fim - própria aos historiadores) ou 'artificial' (in media res - mais apropriada à fabulação poética). Começa ainda no Canto I, quando o poeta relembra os feitos lusitanos na conquista da América: "Rotos os mares, e o comércio aberto, / Já de América o Gênio descoberto / Tinha o Rei Lusitano as grandes terras, / Que o Sul rodeia de escabrosas serras"19. E transcorre ao longo de dez cantos, em rima parelha e versos decassílabos;

$\left.6^{a}\right)$ Epílogo: conclusão ou explicitação esquemática dos fins do poema. Em Vila Rica, pode corresponder ou a todo o último canto ou às suas duas últimas estrofes, quando o poeta relembra, sob os auspícios de Itamonte - a personificação do pico do Itacolomi, em cujas fraudas crescera o arraial de Ouro Preto -, o sentido último do ato fundador: a criação do corpo legislativo, através do qual as diferenças se resolveriam pela palavra: "Ansioso o Povo às portas esperava / Pela alegre notícia, e já clamava Viva o Senado...Viva! Repetia / Itamonte, que ao longe o eco ouvia. // Enfim, serás cantada, Vila Rica, / Teu nome impresso nas memórias fica; / Terás a glória de ter dado o berço / A quem te faz girar pelo Universo. ${ }^{20}$

Quanto ao herói do poema, trata-se, como na Eneida de Virgílio, de um personagem estrangeiro, um fundador que veio de fora. Porém, Albuquerque já é um personagem histórico, cuja vida transcorrera numa época não muito distante do tempo em que viveu o poeta, a ponto de Cláudio Manuel ter acessado a própria memória dos eventos narrados, como ele atesta logo no início do Fundamento histórico: "e só se regula pelo mais crítico e incontestável exame, que por si e por pessoas de conhecida inteligência e probidade pode conseguir sobre fatos que ou a tradição conserva de memória, ou escreveu raramente algum gênio curioso, que o testemunhou de vista" ${ }^{21}$. Curiosos como certo Bento Fernandes Furtado, que teria confiado ao poeta alguns apontamentos que fizera. De resto, quanto a essa proximidade no tempo como fonte da verdade, vale a pena retomar, outra vez, o D. Francisco Xavier de Menezes e suas Advertências preliminares ao seu poema sobre a fundação do Reino de Portugal, que servem como um comentário aos critérios de verdade de Vila Rica: 
porém não se tira daqui a consequência de que tinham por verdadeiro, ou ao menos por tradição provável, tudo o que Homero e Virgílio referem antes, e depois de Tróia abrasada; porque quase tudo é uma fábula heroica fundada sobre poucos fatos verdadeiros para ilustrar a ação, que é o único emprego de um poema épico. Tenho discorrido que os Poetas que tiveram assuntos de mais de quatro, ou cinco séculos, se animarão a alterar as circunstâncias das histórias; (...) Virgílio estava mais longe da incerta expedição de Enéas à Itália, e sabia muito bem, como tão douto, que quase tudo o que escrevia era falso; (...) Lucano, que só viveu no tempo de Nero pouco mais de cem anos mais moderno que a batalha de Farsália, não se atreveu a fingir tanto, parecendo-lhe que a memória, a tradição, as histórias, as inscrições, a medalhas e até as estátuas estavam ainda muito vivas para desmentirem a ação do seu poema, se animosamente desfigurasse com a poesia a verdade da história (...).Voltaire, por esse motivo, alterou pouco a história da Liga na sua Henriade em que conservou os nomes verdadeiros... ${ }^{22}$.

No contexto setecentista, vale dizer, nos poemas de Voltaire e de D. Francisco Xavier de Menezes, a 'verdade da história' é representada nos tumultos dos campos de batalha, que ilustram a ação dos seus respectivos heróis. Henrique de Navarra, no poema voltairiano, sob os auspícios da União Protestante, enfrenta a Liga dos nobres católicos na França do final do século XVI. Ao longo do poema, muitos são os seus feitos: ele rompe o cerco a Paris, atravessa campos de guerra e de fome, faz uso das armas e, já como Henrique IV, coloca em marcha suas tropas quando impedido de assumir o trono, legítimo sucessor que era do rei recém assassinado. Também não faltam episódios de batalhas na épica do D. Francisco Xavier de Menezes sobre a fundação do Reino de Portugal, embora o autor português já indique algo fundamental nas Advertências preliminares ao poema heróico Henriqueida. Em certa passagem, diz ter reservado largo episódio, transcorrido ao longo de três cantos, para descrever jogos e torneios, "porque assim não só faço a ação mais plausível, mas porque me servem muito mais para descobrir, sem a violência da guerra, em que são impróprias as reflexões, o caráter do meu Herói principal, e dos outros, que tem lugar inferior." Xavier de Menezes 
anota algo que seria inteiramente amplificado, depois, por Cláudio Manuel da Costa. De fato, o poema Vila Rica é quase inteiramente reflexivo, vale dizer, voltado nem tanto a representar a violência da guerra ou a excelência das armas, mas a qualidade de um caráter dotado de credibilidade histórica. Lido sob a chave de seu herói principal, o poema parece reposicionar a ordem de prioridades da tradição aristotélica (ainda presentes nos poemas de Voltaire e de Xavier de Menezes): antes de ser a mímesis da ação, a urdidura de Vila Rica é composta pelo retrato quase estático do caráter de Albuquerque. ${ }^{23}$ Como isso fora possível? Três argumentos podem ser evocados para explicitar as razões desse procedimento:

1. Esse traço reflexivo e esse privilégio para o caráter talvez sejam o corolário daquilo que Arbogast Schmitt notou ser a diferença fundamental entre a Poética aristotélica e sua retomada a partir do Renascimento, quando fora reposicionada a relação entre poesia e história, a universalidade e a particularidade dos acontecimentos. A questão que orienta a leitura de Schmitt é a de saber como o poeta poderia cumprir aquelas exigências de universalidade que, em Aristóteles, tornariam a representação poética mais filosófica que a da história. Analisando esse problema a partir dos comentários renascentistas da Poética, Schmitt nota um conjunto de reflexões pautado pela crença de que "a natureza empiricamente dada é por si mesma - individual e coletivamente - universal e exemplar" 24 . Robortello, cujo comentário a Aristóteles foi publicado em 1548, teria elaborado uma equivalência entre o factual, o verdadeiro e o necessário. Para o autor, isso fora possível ao se colocar Aristóteles de ponta-cabeça, uma vez que "o possível não é mais a medida para a configuração da realidade, senão que a realidade é a medida para a invenção de um acontecimento possível" 25 . Em outras palavras, o universal deve ser crível ao público leitor porque compreendido em sua concretude histórica. Assim, a poesia assumiria inteiramente o horizonte do factual: "o poeta há de escolher ações e personagens que, em um sentido empírico (ou segundo o juízo de alguém), são possíveis, que, portanto, 'existam realmente' no mundo"'26. 
2. O segundo argumento já diz respeito a algo interno à obra de Cláudio Manuel da Costa. Pois não é apenas o corpo narrativo do Fundamento histórico que pretende dar chão de credibilidade à composição poética do caráter de Albuquerque. Tanto a Carta Dedicatória ao Conde de Bobadela como o Prólogo ao leitor definem, antecipadamente, todas as virtudes do herói: a "igualdade da justiça”, bem como "o distinto merecimento de um General que tão prudentemente pacificou um Povo rebelde, segurou a Real Autoridade"27. Além disso, ao longo do Fundamento histórico, Cláudio Manuel, gradativamente, indica as correspondências entre os fatos reconstituídos e os episódios dos cantos de Vila Rica. E é importante observar que o próprio poema contém uma série de notas do autor (assim como a Henriade de Voltaire), a partir das quais o poeta reforça a veracidade dos dados representados, faz remissão a fontes pesquisadas ou simplesmente alerta o leitor quando está fabulando em torno da história. Assim, as ações de Antônio de Albuquerque no poema - por exemplo, quando se dirige ao emboaba Nunes Viana -, parecem tão somente ornar um caráter composto, previamente, de um modo unívoco. Tudo se passa como se na Carta Dedicatória, no Prólogo e no corpo do Fundamento histórico o caráter de Albuquerque, totalmente desenhado, fosse a medida prévia para a configuração dos episódios poéticos de Vila Rica, notadamente dos fins primeiros da chegada de Albuquerque às Minas: "Nós juramos das Leis toda a observância, / E do primeiro pacto não devemos / Apartar-nos, pois nele nos prendemos. / Do castigo e do prêmio ele confia / Das minhas mãos o arbítrio; eu deveria / Usar do meu poder; porém cedendo / À piedade o rigor, de vós pertendo / Só dignas provas de obediência pura". ${ }^{28}$

3. Terceiro e último ponto: se o pacto de sujeição que o discurso de Albuquerque evoca é o da Real Autoridade portuguesa, a piedade de seu caráter - fonte de sua prudência e espírito da justiça - tem como modelo o troiano Enéas. Mais importante ainda, esse modelo - certamente bem conhecido do público letrado setecentista - é colocado em epígrafe logo no início da obra, antes mesmo da Carta Dedicatória do Fundamento histórico, antecipando o caráter que será dado a ler. 
"Ultra garamantas, et Indos proferet imperium" - estenderá seu império para além dos Garamantes [povo africano, por metonímia, a África] e dos Indianos: ${ }^{29}$ essa é a epígrafe, retirada do canto VI da Eneida. Retome-se, então, - na tradução de Odorico Mendes - toda a passagem que envolve os versos citados. Essa passagem evoca o momento em que Enéias encontra e escuta os dizeres da sibila. É ela que prediz, para o herói, o futuro: "Do Ítalo tronco os descendentes nossos / Que a fama ilustrarão de seus maiores, hei de explicar-te, e aprenderá teus fados"30 . 'Ítalo tronco', vale dizer, os descendentes do troiano Enéas com a itálica Lavínia, lembra Odorico Mendes em nota explicativa aos versos; tronco esse que, de resto, desembocando em Augusto César, conheceria 'séculos dourados'. Toda essa passagem daria, assim, um tom imperial ao épico de Virgílio e, por extensão, ao caráter de Albuquerque, cujo retrato antecede qualquer episódio 'épico'.

Esse último ponto, ao adentrar pelo problema do tempo da história, merece algum desdobramento. Recorde-se, especialmente, o canto IX de Vila Rica, quando Albuquerque escuta a profecia de Eulina, a evocar, em uma linhagem política, os antecessores do herói no governo das Minas e seus futuros sucessores, a "Encher de lustre a Lusa Monarquia" ${ }^{1}$. É certo que esse artifício poético não engana o leitor: se do ponto de vista dos personagens da epopeia é o futuro que se revela, Cláudio Manuel - e Virgílio - compõe o enredo num tempo em que já sabia o final da história. Mas esse dado, por si mesmo banal, é irrelevante. O que parece estar em jogo, aqui, é um olhar para a história que, embora assentado em uma 'operação historiográfica' por exemplo, em coleta de fontes -, é alheio à ânsia por 'informações novas': à 'memória histórica' não cabe buscar notícias imprevistas às categorias tradicionais do reino lusitano, à poesia não caber 'criar' uma realidade imprevista. ${ }^{32}$ Em outros termos, a profecia de Eulina sugere, para o herói de Vila Rica - e para o leitor do poema -, uma ideia de história 'irrevogável', pautado pela missão imperial, à qual o território conflagrado das pátrias Minas deveria ser, poeticamente, reintegrado. De resto, vale lembrar, com Djalma Espedito de Lima ${ }^{33}$, que o topos da revelação do futuro, enquanto um topos clássico, também aparece em outras épicas luso-coloniais, como o Uraguai (1769) de Basílio da Gama e o Caramuru (1781) de Santa Rita Durão. 
Por tudo isso, é possível que Antônio de Albuquerque tenha um caráter tipicamente imperial. Pois é ele o agente que opera a unidade de um território conflagrado, reintegrando os vassalos rebeldes ao pacto de sujeição da Coroa lusitana. Quando se lê o poema pelos olhos do herói fundador, é como se o futuro da colônia - aquele mesmo futuro desvelado pela Eulina - dependesse da entrada em cena de governantes com esse caráter. Bem semelhante, de fato, à matriz virgiliana, quando a sibila, naquele entrecho da Eneida que antecipa a história por vir, ressalta a missão política do herói: "Enéias será o fundador do que serão os romanos, aos quais 'não dou limites a seu poder, nem no tempo, nem no espaço: dei-lhes um império sem fim.". ${ }^{34}{ }^{35}$ Nessa história, não haveria margem para o indeterminado. Quanto à Vila Rica de Albuquerque, seu futuro deveria estar fixado por um pacto inviolável de sujeição: "Vassalos sois de um Rei, que não vos deve / O cetro ou a coroa; a origem teve / Já dos vossos Senhores; por herança / O Reino Augusto em suas mãos descansa" ${ }^{36}$

Mas, o fato de Antônio de Albuquerque ter esse caráter faria do próprio Cláudio Manuel um poeta tipicamente imperial? Mais ainda, o poema - ou a história das Minas ali contada - deveria ser lido, exclusivamente, pelas lentes do caráter imperial desse herói pacificador? É certo que esse caráter parece ser o traço que articula os diversos fios da poética de Vila Rica. Um intérprete como Djalma Espedito de Lima, inspirado na obra de João Adolfo Hansen sobre as práticas letradas seiscentistas - atento, pois, aos procedimentos retórico-poéticos setecentistas aplicados à forma épica -, destacara, em bacharéis formados nas universidades portuguesas, uma poesia adequada ao decoro da razão de Estado. Vila Rica, nesse sentido, encenaria um herói que, representando El-Rei, teria recomposto a representação hierárquica da metrópole nas Minas coloniais, além de ter glorificado a "ação nobre do herói, representante da Corte portuguesa" ${ }^{37}$. Além disso, ecoando ensaio de Ricardo Martins Valle, Espedito de Lima identifica a civilização alexandrina e Alexandre - "o herói que difundiu o modelo da civilidade entre os povos bárbaros" 38 - como modelos para Albuquerque. Desse ponto de vista, Espedito Lima conclui que, se Cláudio Manuel louvara Albuquerque, assim o fizera para elogiar a própria Capitania de Minas Gerais, vale dizer, a centralidade de suas riquezas minerais no interior do império português. O título dado ao poema faria justiça, assim, não ao nome do herói fundador, mas ao nome da vila que fora fundada, espécie de metonímia das Minas coloniais. 
Hipótese de leitura que, destacando a centralidade do cenário sobre o próprio personagem, cabe reter, embora por outros motivos que os de Espedito de Lima, atento ao caráter exclusivamente imperial do poema. Se Albuquerque é a metonímia de Vila Rica, ou mesmo das Minas coloniais - território atravessado, no início dos setecentos, pelo desordenado de sua conquista e ocupação -, talvez o poema não conte a história, exclusivamente, do ponto de vista de um caráter unívoco, estático e imperial. Essa é a hipótese de leitura de Sérgio Alcides em Estes penhascos ${ }^{39}$, livro criticado por Espedito Lima, embora essa crítica não tenha levado em consideração o coração de seu argumento: o de que Cláudio Manuel não se identificaria totalmente com a linguagem do imperium evocada, no poema, pelos discursos de Albuquerque, mas com as estratégias da negociação ali representadas, a partir das quais os colonos ganhariam seu quinhão de louvor e dignidade. "Reside aí a novidade do Vila Rica na obra claudiana. A terra americana e seus filhos afinal adquirem dignidade suficiente para serem louvados como assunto elevado, em metro heroico e estilo grave. Propõe-se entre americanos e europeus um estatuto de paridade: haveria portugueses 'europeus' e portugueses' paulistas. Tal é o acordo que Cláudio Manuel da Costa põe na mesa de negociações entre a região colonial e o sertão das Minas Gerais, expresso no labirinto do Vila Rica" ${ }^{40}$. Hipótese essa retomada, pelo autor, no ensaio sobre "O lugar não-comum e a república das letras" momentos decisivos de tomada de consciência da condição colonial". ${ }^{4}$

Seguindo as sugestões de Sérgio Alcides, talvez valha a pena destacar que as estratégias de negociação teriam conduzido o poeta a conferir dignidade não apenas aos portugueses paulistas, mas até mesmo aos emboabas rebeldes. É certo que eles seriam movidos pelo "Interesse" - personificação de um vício que também alimentara os sediciosos no poema épico de Voltaire -, cuja influência levara à oposição de dois Frades à chegada de Antônio de Albuquerque nas Minas. Que se recorde certo Frei Menezes, que teria maquinado as primeiras desavenças ao reivindicar, contra os paulistas, até mesmo a ideia de liberdade natural como independência e não-sujeição, numa linguagem sediciosa porque anticolonial: "A liberdade a todos é comua / Ninguém tão louco renuncia à sua". Mas é sobretudo a Nunes Viana, principal líder emboaba, que é feito justiça. No poema épico, Cláudio Manuel destaca o vitupério: 
Confusa multidão, que se prepara

Arrogar-se o Governo e emprende avara

Sustentar com seu sangue o roubo indigno;

De um Chefe os rege o coração maligno,

Bem que se justifique na aparência

De um influxo de zelo e prudência ${ }^{43}$

Mas no Fundamento - que antecede a épica e prepara a leitura dos seus versos - o vitupério, circunscrito à hubris de Viana, é precedida pelo reconhecimento de seu quinhão de glória:

Fazendo, porém, justiça, é certo que entre os rebeldes e levantados daquele tempo, tinha melhor índole que todos o suposto Governador Manuel Nunes Viana; não consta que cometesse, por si ou por algum de seus confidentes, positivamente ação alguma nociva ao próximo; desejava reger com igualdade o desordenado corpo que se lhe ajuntara; acolhia afavelmente a uns e a outros; socorria-os com seus cabedais; apaziguava-os, compunha-os, e os serenava com bastante prudência; ardia porém por ser Governador das Minas e, se tivesse letras, se podia dizer que trazia em lembrança a máxima de César - se as leis devem ser violadas, o direito de governar deve ser violado. ${ }^{44}$

Adriana Romeiro, em sua pesquisa sobre a guerra dos emboabas, acrescenta dados sobre Nunes Viana que vale a pena relembrar. Para a autora, é certo que Albuquerque adentra os sertões num momento em que Nunes Viana estaria combalido, "desmoralizado pelos seus ex-seguidores, que já não o viam mais como o restaurador das minas, mas antes como o usurpador delas ${ }^{\$ 4}$. Mas Viana, continua, fora um emboaba letrado, leitor de obras como História de Portugal restaurado, de D. Luís de Menezes, onde se lê sobre a reconquista da autonomia de Portugal diante da dinastia filipina, através da qual a Coroa é restituída ao herdeiro legítimo, D. João IV, da Casa de Bragança. Viana reconhecera, aqui, a legitimidade do direito de resistência contra a tirania. "Tirania versus liberdade: eis o cerne do discurso emboaba. E o modelo de restauração a que estavam se referindo era indubitavelmente a da Restauração portuguesa. Tal tópica constituía, muito significativamente, o 
centro das teorias políticas gestadas no Portugal restaurado, que legitimavam a resistência popular contra o soberano tirano e injusto" ${ }^{46}$. Se o Estado tem sua origem no pacto, é legítimo que o povo resista quando o soberano deixa de ser ministro do bem comum. Mais ainda, Romeiro nota que as formulações emboabas também criaram a clivagem entre os pobres e os poderosos paulistas, numa incipiente consciência social que, aliás, o próprio Cláudio Manuel notara e elogiara: "desejava reger com igualdade o desordenado corpo que se lhe ajuntara; acolhia afavelmente a uns e a outros; socorria-os com seus cabedais; apaziguava-os, compunha-os, e os serenava com bastante prudência"; afabilidade e prudência que, continua a autora, causara perplexidade a uma das fontes do próprio Cláudio Manuel, qual seja, o conde de Assumar, que em seu Discurso histórico político ${ }^{47}$, por exemplo, reconhece um universo irredutível aos cânones do Estado português.

Por tudo isso, o Fundamento e o poema, embora não reconheçam a dimensão 'letrada' do movimento emboaba, identificam as múltiplas linguagens políticas no território das Minas. Vila Rica talvez seja a tomada de consciência, justamente, dessa multiplicidade, através da qual a história extravasaria o caráter unívoco quando lida do ponto de vista exclusivo da missão imperial de Albuquerque. A rigor, se se retoma, em outro contexto, a leitura de Auerbach $^{48}$ sobre a epopeia, talvez Albuquerque pertencesse, antes de tudo, ao mundo lendário, ainda que seu caráter tenha sido composto não apenas poeticamente, mas também sob os preceitos de uma "memória histórica" acadêmica. Na lenda, haveria "a tendência para a harmonização aplainante do acontecido, para a simplificação dos motivos e para a fixação estática dos caracteres, evitando conflitos, vacilações e desenvolvimento. (...) Como estrutura social, este mundo é totalmente imóvel; as lutas só ocorrem entre diferentes grupos das classes senhoriais; de baixo, nada surge" ${ }^{\text {"49 }}$. Por outro lado, o quadro social e político representado em Vila Rica transcorreria "de maneira muito menos uniforme, mais cheia de contradições e confusão", cada vez mais próximo do que Auerbach sugere como uma estruturação de tipo 'histórico'. ${ }^{50}$

É possível, então, que Cláudio Manuel não tenha invertido tanto assim a ordem de prioridades da Poética aristotélica, tal como descrito na nota número 23 deste artigo. Ao menos se a leitura de Vila Rica deslocar o foco de atenção, do caráter estático de Albuquerque - retratado desde a epígrafe da obra - para 
a multiplicidade das linguagens políticas e das ações dos sertanejos - paulistas ou emboabas. Quando pouco, as 'estratégias de negociação' de Albuquerque, tal como representadas por Cláudio Manuel, parecem levar em consideração a "indomável espontaneidade" do código sertanejo, tão indomável como fora um Borba Gato, assassino de um governador colonial, mas perdoado e reintegrado às conquistas dos sertões (como contado no Fundamento e no canto III de Vila Rica). Em Vila Rica, a harmonização aplainante do acontecido, sob a ótica imperial de Albuquerque, predomina. Mas tanto o poema como seu Fundamento já representariam a tomada de consciência de que o caráter estático e unívoco de Albuquerque não seria a metonímia das Minas - talvez apenas da metrópole -, não representaria, inteiramente, o caráter da história da conquista e ocupação de um outro mundo.

Por fim, vale lembrar que, em 1768, no Prólogo ao leitor das Obras - reunião de poemas impressa em 1768 -, Cláudio Manuel já tinha consciência dos descompassos entre o velho e o novo mundo. As Minas, ao menos, estariam bem longe das "venturosas praias da Arcádia" ${ }_{11}$. Seria impossível, mesmo no plano das convenções bucólicas, substabelecer inteiramente as delícias de Portugal. Razão pela qual o poeta se apresenta, então, sob a persona do 'desconsolado', ou melhor, do desterrado na própria pátria, com tem analisado Sérgio Alcides. Já em 1773, o poeta não se apresenta mais sob tal máscara poética. Vila Rica, porém, também sugere um cenário de inadequações. Cláudio Manuel parece retratar aquilo que Sérgio Buarque, em Metais e pedras preciosas, chamou de "ebulição íntima" 52 , pensada, "claudianamente', com a verdade histórica dos influxos adventícios e com a "ambiciosa fadiga de minerar a terra, que lhes tem pervertido as cores". ${ }^{53}$ 


\section{Notas e Referências}

1 Para Cláudio Manuel, a obra de referência é a edição da Nova Aguilar, que inclui os textos preparados pela Melânia Silva de AGUIAR. A poesia dos inconfidentes, 1996. Já a Arte Poética de Cândido LUSITANO está disponível eletronicamente em: http://archive.org/details/artepoeticaoureg01frei. Por fim, ver também a biografia elaborada por Laura de MELLO E SOUZA. Cláudio Manuel da Costa, o letrado divido. São Paulo: Cia das letras, 2011.

2 Aliás, essas duas feições - a da desordem e a da ordem colonial - são bem conhecidas da historiografia contemporânea, ganhando corpo em obras como Metais e pedras preciosas (1960), de Sérgio BUARQUE DE HOLANDA. Os desclassificados do ouro (1982), de Laura de MELLO E SOUZA, ou, mais recente, Paulistas e emboabas no coração das Mina (2008), de Adriana ROMEIRO, para citar alguns exemplos.

3 Hans BLUMMENBERG. "Imitação da natureza: contribuição à pré-história da ideia do homem criador". In: Luiz COSTA LIMA (org.). Mímesis e a reflexão contemporânea. Rio de Janeiro: Ed. UERJ, 2010, p. 87.

4 ARISTÓTEleS. Poética. Tradução: Eudoro de Souza. $3^{a}$ edição. Lisboa: Imprensa Nacional/Casa da Moeda, 1992, cap. II $1448^{\mathrm{a}}$.

5 Sobre o significado de technê e poiêtike no contexto da poética aristotélica, ver a recente tradução do texto grego em: Fernando Maciel GAZONI. A Poética de Aristóteles: tradução e comentários. São Paulo: Departamento de Filosofia/ USP, 2006. Sobre a racionalidade da 'arte', ver: Enrico BERTI. As razões de Aristóteles. São Paulo: Edições Loyola, 1998.

6 Uma boa introdução sobre a história das 'poéticas' pode ser lida em: Bornheim, Gerd. A Poética de Aristóteles: um delineamento de sua influência histórica. In: Páginas de filosofia da arte. Rio de Janeiro: UAPÊ, 1998. Já uma análise mais circunstanciada dessa história, sobretudo quanto às poéticas renascentistas, pode ser lida em: SCHMITT, Arbogast. Mímesis em Aristóteles e nos comentários da Poética no Renascimento: da mudança do pensamento sobre a imitação da natureza no começo dos tempos modernos. In: COSTA LIMA (org.). Mímesis e a reflexão contemporânea. Rio de Janeiro: Ed. UERJ, 2010; ver também, para as modificações renascentistas da matriz antiga: ADMA MUHANA, A epopeia em prosa seiscentista. São Paulo: Ed. Unesp, 1997. 
7 HORÁCIO. Arte Poética. In: A poética clássica: Aristóteles, Horácio, Longino. Tradução: Jaime Bruna. 12a edição. São Paulo: Ed. Cultrix, 2005, p. 65.

8 Francisco José FR EIRE (Candido Lusitano).. Arte Poética de Q. Horacio Flacco, traduzida e ilustrada em português por Candido Lusitano. Lisboa, Oficina Patriarcal de Francisco Luiz Ameno, 1758, p. 147. (disponível eletronicamente em: http://ia600502.us.archive.org/19/items/c1artepoeticadeq00hora/c1artepoeticadeq00hora.pdf).

9 Idem, p.17-19.

10 É certo que Aristóteles afirma que o poeta bem poderia "fazer uso de sucessos reais" (IX, 1451 b, 27). Mas o ato poético implicaria representar nem tanto a sequência cronológica das ações, mas a composição lógica de uma intriga verossímil e necessária, dotada de unidade e totalidade, tal como analisada nos capítulos VII e VIII da Poética - justamente os que precedem o capítulo que analisa a muito conhecida distinção entre poesia e história.

11 Devo a indicação da obra de D. Francisco Xavier de Menezes a Pedro Telles, a quem agradeço.

12 A este respeito, vale a pena ver, de Adriana Romeiro, "A construção de um mito: Antônio de Albuquerque e o levante emboaba". Esse ensaio não apenas coteja as fontes usadas por Cláudio Manuel como também analisa toda uma tradição historiográfica que assume e desdobra a perspectiva de análise do poeta. Quanto às fontes, a autora nota, por exemplo, que em algumas delas - como os apontamentos de Bento Fernandes Furtado - “Albuquerque está longe de alcançar a relevância que lhe atribui o poeta mineiro, e a sua atuação na pacificação do conflito entre paulistas e emboabas é descrita de forma sucinta e apressada, num tom muito diverso do épico claudiano" (Romeiro, 2009, p.171). Mas o fato interessante é que a simpatia de Albuquerque aos paulistas, tal como exposto por Cláudio Manuel, teria influenciado outras crônicas setecentistas, bem como estudos históricos posteriores, chegando até mesmo ao Affonso de Taunay de História geral das bandeiras paulistas, "empenhado na construção do mito do paulista" (p.174). Por outro lado, o historiador mineiro Isaías Golgher, em Guerra dos emboabas, a primeira guerra civil nas Américas, embora criticasse a visão paulista do conflito e defendesse a causa emboaba, preserva a imagem de Albuquerque como pacificador (p.174). Em resumo, para alguns, Albuquerque é o exemplo do governante eficiente e experimentado na administração colonial, para outros ele é um herói 
civilizador, impetrando leis e justiça num território dominado pela barbárie dos potentados locais (p.176).

13 Cláudio Manuel da COSTA. Vila Rica. In: Domício PROENÇA FILHO (org.). A poesia dos Inconfidentes. Rio de Janeiro: Nova Aguilar, 1996, p. 370.

14 O vocabulário da "conquista" foi corrente na América portuguesa. De certa maneira, os paulistas invocam uma tópica também mobilizada, por exemplo, em Pernambuco, seja pela nobreza da segunda metade do século XVII após a restauração contra o domínio holandês, seja pelos mazombos em suas lutas contra os mascates de Recife (1710-1711), quando a açucarocracia reivindica cargos locais e privilégios fiscais. Esse contexto é analisado por Evaldo Cabral de Mello em A fronda dos mazombos (2003). As Minas setecentistas, por sua vez, são interpretadas pelo livro de Adriana Romeiro sobre a guerra dos emboabas (2008).

15 Adriana ROMEIRO. Paulistas e emboabas no coração das Minas: idéias, práticas e imaginário político no século XVIII. Belo Horizonte: Ed. UFMG, 2008, p. 254.

16 Cláudio Manuel da COSTA. Vila Rica. In: Domício PROENÇA FILHO (org.). A poesia dos Inconfidentes. Rio de Janeiro: Nova Aguilar, 1996, p. 367.

17 Idem, ibdem.

18 Idem, p. 377.

19 Idem, canto I, p. 377.

20 Idem, canto X, p. 446.

21 Idem, p. 360.

22 Francisco Xavier de MENEZES (Conde de Ericeira). Henriqueida: poema heroico com advertências preliminares das regras da poesia épica, argumentos e notas. Lisboa: Officina de Antônio Isidoro da Fonseca, 1741, s/p (disponível eletronicamente em: http://archive.org/details/ henriqueidapoema00eric).

23 Sabe-se que no capítulo VI da Poética, Aristóteles analisa a relação entre ação, caráter e enredo na tragédia, mais precisamente, a primazia da ação sobre o caráter na composição do enredo: "o mais importante entre essas partes é o arranjo das ações, pois a tragédia é mimese não de homens, mas de uma ação e da vida, e a felicidade e a infelicidade encontram-se no agir, e a finalidade da vida é uma certa atividade, não uma qualidade. Segundo o caráter os homens possuem determinadas qualidades, mas é segundo suas 
ações que eles são felizes ou o contrário. Então os personagens não realizam ações com o intuito de mimetizar um caráter, mas adquirem o caráter ao mesmo tempo e graças às ações. De forma que as ações e o enredo são a finalidade da tragédia, e a finalidade é, de tudo, o mais importante. Além disso, sem ação não se faria uma tragédia, mas sem caráter, sim" (Aristóteles, p.56-57). E sobre isso, o tradutor do texto se pergunta em nota: como defender a supremacia da ação sobre o agente (que é quem tem o caráter), se um implica o outro? Duas seriam as prováveis explicações. De um lado, o fim da tragédia "se faz pela mímese de casos que suscitam temor e piedade. As duas emoções, conforme definidas na Retórica, podem estar ligadas a uma reversão da fortuna (...). Essa reversão se dá na ação trágica, e não no caráter dos personagens." De outro lado, na ética de Aristóteles também há prevalência da ação sobre o caráter. As ações moldam o caráter, que, por sua vez, motiva o agir. "Mas cabe às ações o papel flexível nessa relação, são elas que estão sempre abertas aos contrários", logo, à dimensão ética das escolhas (GAZONI, p. 56-57, nota 134 ).

24 Arbogast SCHIMTT. "Mímesis em Aristóteles e nos comentários da "Poética" no Renascimento: da mudança do pensamento sobre a imitação da natureza no começo dos tempos modernos”. In: Luiz COSTA LIMA (org.). Mímesis e a reflexão contemporânea. Rio de Janeiro: Ed. UERJ, 2010, p. 152.

25 Idem, p. 176.

26 Idem, p. 185.

27 Cláudio Manuel da COSTA. Vila Rica. In: Domício PROENÇA FILHO (org.). A poesia dos Inconfidentes. Rio de Janeiro: Nova Aguilar, 1996, p. 359.

28 Idem, canto I, p.411.

29 Idem, p. 356.

30 VIRGílio. Eneida brasileira ou tradução poética da epopeia de Públio Virgílio Maro. Tradução: Odorico Mendes. Campinas: Ed. Unicamp, 2008, p. 253.

31 Cláudio Manuel da COSTA. Vila Rica. In: Domício PROENÇA FILHO (org.). A poesia dos Inconfidentes. Rio de Janeiro: Nova Aguilar, 1996, p. 430-34.

32 Ainda que em outro contexto, conferir, de Hannah Arendt, "O conceito de história - antigo e moderno" (1992, p. 74-75), quando a autora evoca, na Odisséia, o episódio de Ulisses na corte dos Feácios, escutando da boca de um aedo o canto de suas próprias aventuras. Segundo Arendt, o que era simples 
ocorrência se transforma em história, cuja medida da grandeza não se dava pela novidade mas pela excelência dos feitos do herói.

33 Djalma Espedito de LIMA. A épica de Cláudio Manuel da Costa: uma leitura do poema Vila Rica. São Paulo: Faculdade de Filosofia, Letras e Ciências Humanas, 2007 (disponível eletronicamente em: http://www.teses.usp.br/ teses/disponiveis/8/8149/tde-25022008-103758/pt-br.php), p. 50-3.

34 Costa Lima analisa a Eneida como uma épica imperial, que supõe a conjuntura política contemporânea do império de Augusto: "a identidade romana que o poema procura fortalecer já deixara de ser nacional, tornara-se imperium terris" (Luiz COSTA LIMA. História. Fiç̧ão. Literatura. São Paulo: Cia das letras, 2006, p.212). Para o autor, é o caso de relembrar essa questão por dois motivos precisos. Trata-se, num primeiro momento, de pensar a relação entre certeza do futuro e a pouca margem para o indeterminado e para a composição ficcional. Num segundo passo, Costa Lima analisa porque essa certeza, enquanto modo de ressaltar o imperium, tivera repercussão para além de Roma - e o caso luso-colonial, não analisado pelo autor, pode bem exemplificar esse passo. Nesse sentido, talvez se possa acrescentar aos argumentos do autor que Virgílio fundara uma poesia imperial na mesma medida em que Roma teria "feito advir no seio do 'concreto', o da História e das instituições, essa exigência de universalidade que define a filosofia" (François JULLIEN. O diálogo entre as culturas: do universal ao multiculturalismo. Rio de Janeiro: Jorge Zahar Editor, 2009, p.63). Mediante a lei e o status jurídico da cidadania romana, o universal buscado pela filosofia - ou pela representação poética - entra no domínio do império legal, vale dizer, do vínculo entre a "Cidade e o mundo, a urbs e o orbis" (François JULLIEN. Opus cit. p.63). "Daí a ideia que vemos celebrada pelos próprios romanos, segundo a qual, ao unificar o conjunto dos homens sob o direito, encontrando para eles uma pátria comum, Roma, consumando a natureza, devolveu o homem à sua humanidade (retirou-o de sua 'imanidade', immanitas). Dissipa-se definitivamente a separação grega entre helenos e bárbaros" (François JULLIEN. Opus cit. p.68). De resto, se Cláudio Manuel é leitor de Virgílio e dos romanos, não é menos importante lembrar, mais uma vez, que também fora um poeta formado em Cânones em Coimbra. O universal poético, a história e a realidade das instituições lusitanas parecem se articular, em Vila Rica, mediados pelo universo legal do imperium, bem 
representado pelo caráter de Antônio de Albuquerque e de seus discursos ao longo do poema.

35 Luiz COSTA LIMA. História. Fiç̧ão. Literatura. São Paulo: Cia das letras, 2006, p. 217.

36 Cláudio Manuel da COSTA. Vila Rica. In: Domício PROENÇA FILHO (org.). A poesia dos Inconfidentes. Rio de Janeiro: Nova Aguilar, 1996, canto IX, p. 439.

37 Djalma Espedito de LIMA. A épica de Cláudio Manuel da Costa: uma leitura do poema Vila Rica. São Paulo: Faculdade de Filosofia, Letras e Ciências Humanas, 2007 (disponível eletronicamente em: http://www.teses.usp.br/ teses/disponiveis/8/8149/tde-25022008-103758/pt-br.php), p. 24.

38 Idem, p. 88.

39 Sérgio ALCIDES. Estes penhascos: Cláudio Manuel da Costa e a paisagem das Minas - 1753-1773. São Paulo: Hucitec, 2003.

40 Idem, p. 237.

41 Sérgio ALCIDES. O lugar não-comum e a república das letras. Revista do Arquivo Público Mineiro. Belo Horizonte: jul./dez. 2008, volume 4, fascículo 2.

42 Idem, p. 45.

43 Cláudio Manuel da COSTA. Vila Rica. In: Domício PROENÇA FILHO (org.). A poesia dos Inconfidentes. Rio de Janeiro: Nova Aguilar, 1996, canto V, p. 406.

44 Idem, p. 370.

45 Adriana ROMEIRO. Paulistas e emboabas no coração das Minas: idéias, práticas e imaginário político no século XVIII. Belo Horizonte: Ed. UFMG, 2008, p. 273.

46 Idem, p. 267.

47 Apud: Laura de MELLO E SOUZA. Discurso histórico e político sobre a sublevação que nas Minas houve no ano de 1720. Belo Horizonte: Fundação João Pinheiro, 1994.

48 Erich AUERBACH. Mimesis. 4ª edição. São Paulo: Ed. Perspectiva, 1998.

49 Idem, p. 17-18.

50 Idem, p. 16.

51 Cláudio Manuel da COSTA. Vila Rica. In: Domício PROENÇA FILHO (org.). A poesia dos Inconfidentes. Rio de Janeiro: Nova Aguilar, 1996, p. 47. 
52 Sérgio Buarque de HOLANDA. Metais e pedras preciosas. In: HOLANDA (org.). História Geral da Civilização Brasileira. São Paulo: Difel, 1960 (v. I, tomo II), p. 47.

53 Cláudio Manuel da COSTA. Vila Rica. In: Domício PROENÇA FILHO (org.). A poesia dos Inconfidentes. Rio de Janeiro: Nova Aguilar, 1996, p. 47.

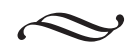

